Szepelska A., Samozatrudnienie jako forma wspierania rozwoju przedsiębiorczości regionów, „Ekonomia i Prawo", Polszakiewicz B., Boehlke J. (red.), Tom XII, nr 1/2013, ss. 69-80 DOI: http:// dx.doi.org/10.12775/EiP.2013.006

\title{
SAMOZATRUDNIENIE JAKO FORMA WSPIERANIA ROZWOJU PRZEDSIĘBIORCZOŚCI REGIONÓW
}

\author{
STRESZCZENIE
}

Samozatrudnienie jest jedną z form skutecznego przeciwdziałania bezrobociu, podnoszenia poziomu aktywności zawodowej społeczeństwa, a także stymulowania rozwoju ekonomicznego i społecznego regionów. Poziom rozwoju całego sektora MSP w Polsce odbiega jednak od średniej dla UE. Wskazuje na to relatywnie niski poziom liczby pracujących, w szczególności w mikro i małych firmach, produktywności, a także skala działalności. Pomimo dynamicznej poprawy na przestrzeni lat, możliwości dalszego rozwoju samozatrudnienia są ograniczone. W niwelowaniu barier może pomóc prawnie ustalony obowiązek samorządu terytorialnego do wspierania przedsiębiorczości w regionie. Zgodnie z ustawą o samorządzie terytorialnym, władze jednostek administracyjnych mają obowiązek zapewnić trwały rozwój regionu poprzez wspieranie przedsiębiorczości. Celem artykułu jest wskazanie na samozatrudnienie jako jednej $\mathrm{z}$ form wspierania rozwoju przedsiębiorczości regionów.

Słowa kluczowe: samozatrudnienie, przedsiębiorczość regionów Klasyfikacja JEL: E24, L26

* Alina Szepelska, Państwowa Wyższa Szkoła Informatyki i Przedsiębiorczości w Łomży, Instytut Przedsiębiorczości, ul. Akademicka 14, 18-400 Łomża, e-mail: ala@fina.pl. 


\title{
SELF-EMPLOYMENT AS MEANS OF REGIONS' ENTREPRENEURSHIP DEVELOPMENT
}

\author{
SUMMARY
}

Self-employment is one amongst many other forms of efficient prevention of unemployment, raising the level of economic and social activity of society across regions. The level of development of Small and Medium Enterprises in Poland differs from the European Union`s average. The relatively low number of employees, especially in micro and small enterprises and the scale of activities prove this thesis. Despite rapid improvement over the years, the possibilities of further development of self-employment are limited. The obligation of Local Authorities that will be enforced by law, to support the development of entrepreneurship in the region may help to reduce the barriers. According to the Local Government Act, local authorities are obliged to ensure the constant development of regions by supporting entrepreneurship. The main goal of this article is to show that self-employment is one of the forms of the regions' entrepreneurship development.

Keywords: self-employment, regions' entrepreneurship

JEL Classification: E24, L26

\section{WSTĘP}

Samozatrudnienie w krajach wysoko rozwiniętych traktowane jest jako przejaw indywidualnej przedsiębiorczości ${ }^{1}$, nakierowanej na działalność gospodarczą, zapewniającej jednostce pracę przynoszącą dochód. Rozwój samozatrudnienia jest jedną $\mathrm{z}$ form skutecznego przeciwdziałania bezrobociu, podnoszenia poziomu aktywności zawodowej społeczeństwa, a także stymulowania rozwoju ekonomicznego i społecznego regionów oraz kraju. W kontekście tych definicji można pozytywnie ocenić potencjalne znaczenie samozatrudnienia $\mathrm{w}$ gospodarce.

W Polsce ekspansja małych oraz mikro firm nastąpiła w okresie transformacji gospodarki. Zasadniczą rolę odegrało wówczas upowszechnienie nowych technologii informacyjnych i telekomunikacyjnych, co spowodowało łatwiejszy i stały dostęp do informacji, niższe koszty transakcyjne czy zbliżenie geograficzne rynków. Drobny biznes stawał się również atrakcyjny w tradycyj-

${ }^{1}$ E. Gąsiorowska, D. Witczak-Roszkowska, Portret osób przedsiębiorczych, [w:] K. Piech, M. Kulikowski (red.), Przedsiębiorczość szansq na sukces rzqdu, gospodarki, przedsiębiorstw, spoteczeństwa, Instytut Wiedzy, Warszawa 2002, s. 17. 
nych branżach, które zaspokajają popyt na dobra i usługi niestandardowe, dostosowane do indywidualnych potrzeb klientów.

W Unii Europejskiej ok. 32 miliony ludzi mają status samozatrudnionych, co stanowi prawie 15\% ogólu pracujących ${ }^{2}$. W Polsce mikroprzedsiębiorstwa, w których osoby fizyczne stanowią $95 \%$ populacji, dają pracę ponad jednej trzeciej pracujących w firmach $(37,5 \%)$. Odsetek małych firm opartych na samozatrudnieniu, nastawionych na rozwój, wynosi $26 \%$. Jest to zatem spory potencjał w wytwarzaniu wartości dodanej i tworzeniu miejsc pracy, a także nie mniej ważny dla kreowania innowacyjności ${ }^{3}$.

$\mathrm{W}$ powstawaniu i rozwoju przedsiębiorstw $\mathrm{w}$ ramach samozatrudnienia istotne znaczenie ma identyfikacja barier. Statystyki europejskie wskazują, że odsetek upadających przedsiębiorstw jest najwyższy kolejno wśród firm opartych wyłącznie na samozatrudnieniu i wśród mikroprzedsiębiorstw, choć ich powstawanie jest silnie zdeterminowane przez cele i potrzeby właścicieli, a więc teoretycznie powinny być podmiotami ekspansywnymi, innowacyjnymi.

W niwelowaniu barier może pomóc prawnie ustalony obowiązek samorządu terytorialnego do wspierania przedsiębiorczości w regionie. Zgodnie z ustawą o samorządzie terytorialnym, władze jednostek administracyjnych mają obowiązek zapewnić trwały rozwój regionu poprzez wspieranie przedsiębiorczości ${ }^{4}$.

Celem artykułu jest wskazanie na samozatrudnienie jako jednej $z$ form wspierania rozwoju przedsiębiorczości regionów godnej poświecenia uwagi polityki władz lokalnych. Zrealizowaniu celu służą oparte na literaturze przedmiotu analizy teoretyczne oraz porównawcze.

\section{SAMOZATRUDNIENIE A PRZEDSIĘBIORCZOŚĆ INDYWIDUALNA}

Tradycyjnie przedsiębiorczość postrzegana była jako zjawisko związane z uruchamianiem i prowadzeniem małego przedsiębiorstwa. Obecnie tę definicję można odnieść do samozatrudnienia jako przejawu przedsiębiorczości indywidualnej wśród osób, które chcą prowadzić własne małe przedsiębior-

${ }^{2}$ Dokument roboczy Sekcji Jednolitego Rynku, Produkcji i Konsumpcji w sprawie samozatrudnienia, Europejski Komitet Ekonomiczno-Społeczny, Bruksela 2012.

${ }^{3}$ Raport o stanie matych $i$ średnich przedsiębiorstw w Polsce, PARP, Warszawa 2011, s. 49.

${ }^{4}$ E. Skowron, Efektywnośc polityki wtadz lokalnych we wspieraniu rozwoju przedsiębiorczości na przyktadzie regionu częstochowskiego i tódzkiego, [w:] N. Daszkiewicz (red.), Mate i średnie przedsiębiorstwa. Szanse i zagrożenia rozwoju, CeDeWu.pl, Warszawa 2007, s. 178. 
stwo ${ }^{5}$ Zwrot „przedsiębiorczość indywidualna” powinna zatem kojarzyć się z samozatrudnieniem ${ }^{6}$.

Pojęcie samozatrudnienia definiowane jest w różny sposób, w zależności od kontekstu w jakim termin ten jest używany ${ }^{7}$. Samozatrudnienie, praca na własny rachunek, indywidualna działalność gospodarcza, działalność gospodarcza osób fizycznych, działalność na własny rachunek, firma jednoosobowa - to wiele nazw na oznaczenie w praktyce takiej samej sytuacji, w której osoba fizyczna podejmuje działalność gospodarczą na własny rachunek i na własne ryzyko. Firma i osoba przedsiębiorcy w samozatrudnieniu stanowią jedność i nie można rozpatrywać tych dwóch elementów oddzielnie ${ }^{8}$. $Z$ punktu widzenia teorii przedsiębiorczości samozatrudniający jest przedsiębiorcą ${ }^{9} \mathrm{Z}$ punktu widzenia rynku pracy samozatrudnienie jest alternatywnym sposobem zatrudniania. W ramach samozatrudnienia coraz bardziej popularne staje się te $\dot{z}$ świadczenie usług, zarówno w ramach prowadzonej działalności, jak i na rzecz innych podmiotów ${ }^{10}$.

W Raporcie o stanie sektora MSP w Polsce pojęcie samozatrudnienia pod względem formy organizacyjno-prawnej rozumiane jest jako ${ }^{11}$ : zjawisko związane $\mathrm{z}$ przedsiębiorcą, który zakłada własną firmę. Zatrudnienie $\mathrm{w}$ takim przedsiębiorstwie początkowo znajduje wyłącznie jej właściciel, a forma prawna firmy to najczęściej indywidualna działalność osoby fizycznej. W miarę rozwoju i wzrostu firmy może ona zwiększać swoje zatrudnienie, obszar działalności, liczbę klientów, jak i zmienić formę prawną prowadzenia działalności, jednak nadal założyciela takiej firmy określać się będzie osobą samozatrudnioną, a firmę nazywać samozatrudnieniową.

$\mathrm{Na}$ podstawie literatury tematu można wyróżnić trzy grupy przedsiębiorców podejmujących decyzję o samozatrudnieniu ${ }^{12}$ : pierwsza grupa osób to przedsiębiorcy, dla których samozatrudnienie to okres przejściowy, druga grupa to osoby, w których planach zawodowych nie znajduje się stworzenie dużego przedsiębiorstwa. Osoby takie to samozatrudnieni sensu stricto, trzecią

${ }^{5}$ C. A. Kent, Rola przedsiębiorcy w gospodarce, [w:] D. R. Kamerschen, R. B. McKenzie, C. Nardinelli, Ekonomia, Fundacja Gospodarcza NSZZ, Gdańsk 1993, s. 542-543.

${ }^{6}$ A. Lemańska-Majdzik, Czynniki sukcesu firm powstatych w wyniku samozatrudnienie, Wydawnictwo Uniwersytetu Łódzkiego, Łódź 2006, s. 29-42.

7 B. Piasecki, Przedsiębiorczośc i mata frrma. Teoria i praktyka, Wydawnictwo Uniwersytetu Łódzkiego, Łódź 1998, s. 97.

${ }^{8}$ Dictionary.LaborLawTalk.com.

9 B. Piasecki, op. cit., s. 97.

10 Ł. Pisarczyk, Różne formy zatrudnienia, Dom Wydawniczy ABC, Warszawa 2003, s. 134.

${ }_{11}$ Raport o stanie sektora MSP w Polsce w latach 2004-2005, PARP, Warszawa 2005, s. 219.

${ }^{12}$ www.samozatrudnieniu.pit.pl. 
grupę stanowią pracownicy, którzy zorganizowali formalnie swoją aktywność zawodową w postaci jednoosobowej działalności gospodarczej.

Niezależnie jednak od powodów podjęcia decyzji o samozatrudnieniu, każda $\mathrm{z}$ wyżej wymienionych grup przedsiębiorców niewątpliwie musi wykazywać się pewnym poziomem przedsiębiorczości.

Poziom przedsiębiorczości, mierzony liczbą firm na tysiąc mieszkańców w Polsce, znajduje się nieco poniżej średniej UE (40 do 42). Najbardziej przedsiębiorczym w tym ujęciu narodem w UE jest Portugalia - 80, Grecja - 74, najmniej: Słowacja - 11,5 i Rumunia - 10. Lepszy od średniej UE wynik jako kraj osiągamy pod względem odsetka osób dorosłych, które założyły własną firmę lub podejmują działania w tym kierunku oraz odsetka osób, które preferowałyby własną działalność gospodarczą (odpowiednio 14\% do 12\% i $49 \%$ do $45 \%)^{13}$.

Jeśli chodzi natomiast o poziom przedsiębiorczości poszczególnych województw, biorąc pod uwagę najważniejsze wskaźniki przedsiębiorczości to pod względem liczby MSP na 1000 mieszkańców na pozycję lidera wysunęło się woj. zachodniopomorskie, nieznacznie wyprzedzając woj. mazowieckie. Biorąc pod uwagę nowo powstałe i zlikwidowane przedsiębiorstwa na 1000 mieszkańców to województwa Polski wschodniej wypadają słabo w kwestii nowo powstałych, jednak dużo lepiej niż w przypadku liczby zlikwidowanych podmiotów. Jeśli chodzi natomiast o nakłady inwestycyjne i źródła ich finansowania to głównym źródłem finansowania inwestycji we wszystkich regionach były środki własne, a kolejnym pod względem wielkości finansowania źródłem, dla wszystkich województw z wyjątkiem pomorskiego - kredyty i pożyczki krajowe. Środki zagraniczne nadal nie są popularne wśród firm z sektora MSP. Środki budżetowe także nie są często wykorzystywane przez przedsiębiorców, jednak gdy ma to miejsce, dzieje się tak głównie we wschodniej Polsce (lubelskie, świętokrzyskie, podlaskie). Podsumowując, najsłabsze rezultaty w większości wyżej wymienionych wskaźników zanotowały województwa wschodniej Polski ${ }^{14}$.

\section{ZJAWISKO SAMOZATRUDNIENIA NA TLE UE}

Zjawisko samozatrudnienia znane jest w krajach wysoko rozwiniętych od wielu lat. W krajach UE w tej formie produkcji pracuje obecnie około $15 \%{ }^{15}$.

\footnotetext{
13 Raport o stanie matych i...

${ }^{14}$ Ibidem.

15 Dokument roboczy Sekcji Jednolitego Rynku...
} 
Rozwój samozatrudnienia w Unii Europejskiej był efektem kolejnego etapu procesu rozwoju rynku pracy. W strukturze firm MSP działających w UE-27, uwagę zwraca ponad dwukrotnie większy odsetek firm małych (7\%).

W porównaniu z innymi krajami członkowskimi UE w Polsce przeciętna liczba istniejących MSP na 1000 mieszkańców jest poniżej średniej unijnej. W Polsce przypada 368 małych i średnich firm na 1000 mieszkańców w wieku produkcyjnym, gdzie dla porównania w Czechach 860 MSP. Według danych GUS (za 2009 r.) w Polsce działa 1,67 mln przedsiębiorstw, z czego większość $(99,8 \%)$ to małe i średnie przedsiębiorstwa. Sektor MSP w Polsce w większym stopniu niż w UE jest zdominowany przez mikrofirmy, których udział w całkowitej liczbie przedsiębiorstw (96\%) przewyższa średnią europejską (91,8\%). 1,6 mln mikroprzedsiębiorstw w Polsce daje nam drugi najwyższy wynik w $\mathrm{UE}^{16}$.

Znaczenie mikrofirm w Polsce jest nieco większe niż przeciętnie w krajach UE. Mają one nieco większy udział w liczbie firm i wartości dodanej brutto przedsiębiorstw oraz wyraźnie większy, jeśli chodzi o udział w obrotach i tworzeniu miejsc pracy. Dają one pracę ponad jednej trzeciej pracujących w firmach $(37,5 \%)$, generują jedną czwartą obrotów $(26,9 \%)$ i wartości dodanej brutto $(21,6 \%)$ oraz jedną siódmą inwestycji (14,2\%). Mimo to produktywność mikrofirm w Polsce - mierzona wartością dodaną brutto generowaną przez jednego pracującego - stanowi około jednej trzeciej (31\%) wyników firm UE. Wyraźnie lepiej niż UE wypadamy natomiast pod względem wartości dodanej na 1 EUR wynagrodzenia - wskaźnik ten dla mikrofirm w Polsce (3,3 EUR) jest o 16\% wyższy niż UE (2,8 EUR). Na korzyść należy ocenić również tempo zmian - wszystkie wyżej wymienione wartości dla mikrofirm w Polsce, poza wynagrodzeniami, rosną szybciej niż przeciętnie w $\mathrm{UE}^{17}$.

Pomimo faktu, że udział mikrofirm w liczbie przedsiębiorstw ogółem w Polsce spada, to liczba tych podmiotów w naszym kraju wykazuje tendencję wzrostową. Tylko w 2009 r. powstało ich aż o 70 proc. więcej niż w 2004 r., co przekłada się na wzrost liczby nowych firm z 200 tys. do blisko 350 tys. Według danych Eurostatu w latach 2003-2009 liczba mikroprzedsiębiorstw w Polsce wzrosła o 7,2\%, jednak wolniej niż w UE-27 (12,2\%) i wzrost PKB w naszym kraju (30\%), co wskazuje raczej na wzrost wielkości firm niż ich liczby ${ }^{18}$.

W grupie mikroprzedsiębiorstw osoby fizyczne stanowią $95 \%$ populacji. $\mathrm{Z}$ tego ponad dwie trzecie przedsiębiorców to osoby samozatrudnione, pro-

\footnotetext{
${ }^{16}$ Raport o stanie matych i...

17 Ibidem.

${ }^{18}$ Ibidem.
} 
wadzące jednoosobową działalność gospodarczą (69,8\%, tj. 1,1 mln). Udział samozatrudnionych w ogólnej liczbie mikrofirm jest tym wyższy im młodszą grupę firm rozpatrujemy - stanowią oni $90 \%$ firm funkcjonujących do pierwszego roku działalności. Co czwarta najmniejsza firma jest prowadzona przez osobę, dla której jest to dodatkowe miejsce pracy. Samozatrudnieni dominują w liczbie firm wszystkich branż gospodarki, jednak w największym stopniu w branżach usługowych (85\%). Najmniej samozatrudnionych pracuje w handlu (60\%) i przemyśle (62). Koncentracja we wskazanych branżach świadczy o pewnej specyfice tych segmentów rynku, na których z powodzeniem może funkcjonować niewielki podmiot odpowiadając na lokalny i ograniczony popyt ${ }^{19}$.

Analizując wyniki finansowe samozatrudnionych i pozostałych przedsiębiorstw można zauważyć, że te pierwsze, pomimo, że jest ich ponad dwa razy więcej generują ponad dwa i pół raza mniej przychodów ogółem (144,3 mld PLN do 374,9 mld PLN). Wynika to z faktu, że samozatrudnieni cechują się znacznie mniejszą skalą działalności niż pozostałe mikroprzedsiębiorstwa. Ponadto, samozatrudnieni stosunkowo rzadko stawiają na rozwój. Nakłady zaś na środki trwałe samozatrudnionych są cztery razy mniejsze niż wśród pozostałych mikrofirm (jedynie 3,7 tys. PLN przy 15,5 tys. PLN przeciętnie dla pozostałych przedsiębiorstw ${ }^{20}$. $Z$ drugiej jednak strony, z punktu widzenia rentowności działalności gospodarczej, samozatrudnieni (z wynikiem 24\%) prezentują się wyraźnie lepiej niż pozostałe przedsiębiorstwa (10\%).

\section{SZANSE I BARIERY ROZWOJU SAMOZATRUDNIENIA}

Rozwój samozatrudnienia będący przejawem indywidualnej przedsiębiorczości jest pozytywnym zjawiskiem. Ze względu na istniejący obecnie niewystarczający przyrost nowych miejsc pracy forma tworzenia własnego miejsca pracy ma bardzo istotne znaczenie. Dodatni wpływ samozatrudnienia na wzrost liczby miejsc pracy wynika $\mathrm{z}$ tego, że założenie i rozwój własnej firmy mogą być związane $z$ zatrudnianiem osób w kolejnych okresach. Poza tym, samozatrudnienie wzbogaca rynek pracy poprzez możliwość wykonywania pracy poza tradycyjną umowę o pracę. Wpływa to na skalę uelastycznienia rynku pracy postrzeganego jako sprawna reakcja tego rynku na wahania produkcji.

Kolejnym powodem pozytywnego oddziaływania samozatrudnienia na gospodarkę jest wpływ tej formy prowadzenia działalności na aktywność go-

\footnotetext{
${ }^{19}$ Ibidem.

${ }^{20}$ Ibidem.
} 
spodarczą. Zależność ta jest najbardziej widoczna w okresach słabej koniunktury gospodarczej, kiedy to zagrożenie przed zwolnieniami wywołuje ze strony pracownika skłonność do działań zmierzających do utrzymania dotychczasowego poziomu dochodu. Podjęcie w takiej sytuacji własnej działalności wyzwala przedsiębiorczość, inwencję i wynikającą z niej aktywność gospodarowania, która jest $z$ kolei treścią ożywienia gospodarczego.

Źródłem ożywienia jest także obniżka kosztów pracy w istniejących przedsiębiorstwach. W okresie silnego obniżenia tempa wzrostu gospodarczego większość firm myśli nie o rozwoju, lecz o przetrwaniu, stąd troska o koszty ${ }^{21}$. Możliwość obniżenia kosztów poprzez przejście pracowników na własną działalność zwiększa szanse na przetrwanie firmy w okresie spadku popytu z punktu widzenia redukcji obciążeń pozapłacowymi kosztami pracy.

Polacy najchętniej zakładają najmniejsze firmy. Polskie mikrofirmy nie chcą się rozwijać pod kątem zwiększania liczby pracowników, ponieważ nakłada to na nich dodatkowe obowiązki prawne i biurokratyczne. Przedsiębiorcy bardziej preferują założenie kolejnego mikropodmiotu, niż rozszerzenie obecnego. Takie rozdrobnienie działalności ma na celu minimalizację ryzyka i ewentualnych strat zainwestowanego kapitału. Ma to związek również z tym, iż polską przedsiębiorczość charakteryzuje niski wskaźnik przeżywalności w pierwszych trzech latach. Udaje się to co trzeciej firmie, podczas gdy w rozwiniętych gospodarkach przeżywa 50-70\% świeżo rozpoczętych biznesów ${ }^{22}$.

Prowadzenie działalności gospodarczej w Polsce według światowych rankingów nie wygląda na łatwe. Według raportu Doing Business 2011 Polska nie wypada najlepiej - 70. miejsce na 183 sklasyfikowane kraje. O ile kraje Europy Środkowej i Wschodniej są jednymi z najszybciej reformujących się regionów na świecie, o tyle Polska w tym gronie robi to najwolniej ${ }^{23}$.

Zwiększenie atrakcyjności samozatrudnienia wymaga zmian legislacyjnych, obniżenia podatków i uproszczenia formalności związanych z rozpoczynaniem działalności gospodarczej.

Niezbyt sprzyjające warunki prowadzenia działalności gospodarczej w Polsce sprawiają, że poziom rozwoju mikrofirm w Polsce odbiega od średniej dla UE. Wskazuje na to relatywnie niski poziom liczby pracujących (oraz zatrudnienia), produktywności - wyrażony wartością dodaną brutto, a także skala działalności - średnie obroty czy ograniczona obecność na rynkach za-

21 Z. Woźniakowski, Samozatrudnienie - sposób na bezrobocie, „Gazeta Prawna”, 2002, nr 39.

22 http://alinawarzecha.blogspot.com/2011/09/przedsiebiorczosc-polakow.html.

23 Doing Business 2010, 2011, The International Bank for Reconstruction and Development/ The World Bank. 
granicznych. Nadal niezadowalająca jest skala działań na rzecz rozwoju - poziom inwestycji oraz zainteresowanie innowacjami i $\mathrm{B}+\mathrm{R}$.

Niemniej jednak, Polacy bardziej niż stara Europa upatrują swoją przyszłość we własnej firmie i samorozwoju zamiast w dużej korporacji - jak wynika z Eurobarometru „Przedsiębiorczość w Europie i poza nią" ${ }^{24}$. Prawie co drugi Polak (49\%) chciałby prowadzić własny biznes.

W niwelowaniu barier może pomóc prawnie ustalony obowiązek samorządu terytorialnego do wspierania przedsiębiorczości w regionie. W celu oddziaływania na gospodarkę lokalną władze samorządowe mogą korzystać ze środków prawno-administracyjnych, ekonomiczno-finansowych czy związanych z własną działalnością gospodarczą ${ }^{25}$.

\section{ZAKOŃCZENIE}

Zjawisko rozwoju przedsiębiorczości indywidualnej stymulującej samozatrudnienie jest sytuacją pozytywną zarówno dla przedsiębiorców, jak i dla rozwoju gospodarczego regionów. Trudno zatem przecenić znaczenie badań nad uwarunkowaniami przedsiębiorczości indywidualnej, związanej z działalnością prowadzoną na własny rachunek.

Samozatrudnienie definiowane jako przedsiębiorczość indywidualna ma swoje atuty ale i ograniczenia. Do podstawowych atutów zaliczyć można m.in. indywidualną własność, z którą wiąże się całkowita identyfikacja właściciela z sukcesem firmy, pełna niezależność w podejmowaniu decyzji i całkowite zaangażowanie w działalność firmy, kompleksowy charakter zarządzania firmą czy mało zbiurokratyzowany system kontroli ${ }^{26}$. Osoby samozatrudnione są bardziej usatysfakcjonowane zawodowo niż pracownicy najemni ${ }^{27}$. Z globalnego natomiast punktu widzenia rozwój samozatrudnienia ma niebagatelne znaczenie dla ograniczania bezrobocia. Stwarza możliwość dla osób poszukujących zatrudnienia powrotu do zasobu pracujących. Dodatkowo uruchomienie działalności gospodarczej daje szansę na tworzenie nowych miejsc pracy w przyszłości dla pracowników najemnych. Ograniczenia natomiast to prze-

24 S. Czubkowska, Polacy chca pracować na wtasnym, „Gazeta Prawna”, z dnia 15.06.2010.

25 E. Skowron, op. cit., s. 178.

26 A. Lemańska-Majdzik, E. Stawasz, Samozatrudnienie - aktywne formy przeciwdziatania bezrobociu - doświadczenia krajowe i zagraniczne, [w:] H. Skłodowski, E. Stawasz (red.), Psychologiczne wyznaczniki poszukiwania pracy $i$ samozatrudnienia w regionach zmarginalizowanych, Uniwersytet Łódzki, Łódź 2007, s. 24.

${ }^{27}$ D. G. Blanchflower, Self-employment in OECD countries, NBER Working Paper Series, National Bureau of Economic Research 2000, s. 26. 
de wszystkim obok niskiej produktywności, niezadowalającej skali działań na rzecz rozwoju czy brak dostępu do kapitału, który w bezpośredni sposób wpływa na rozwój tego typu działalności.

Pomimo barier ograniczających rozwój samozatrudnienia, nowi przedsiębiorcy coraz chętniej myślą o podjęciu własnej działalności gospodarczej na zasadach samozatrudnienia. Badania Kelly Services, globalnego dostawcy rozwiązań w zakresie HR wykazały, że kryzys gospodarczy w Polsce wykreował nowe podejście do przedsiębiorczości na rynku pracy - większą otwartość na rożne formy samozatrudnienia.

Biorąc pod uwagę otwartość Polaków na samozatrudnienie, ale przede wszystkim niebagatelne znaczenie tej formy działalności gospodarczej dla rozwoju regionów zarówno pod względem przyrostu nowych miejsc pracy jak i niwelowania bezrobocia, powinna być ona wspierana zarówno przez programy rządowe jak i władze jednostek administracyjnych.

\section{BIBLIOGRAFIA}

Bezrobotni oraz stopa bezrobocia wedtug województw, podregionów i powiatów, GUS, Warszawa, kwiecień 2010.

Blanchflower D.G., Self-employment in OECD countries, NBER Working Paper Series, National Bureau of Economic Research 2000, http://dx.doi.org/10.1016/ S0927-5371(00)00011-7.Czubkowska S., Polacy chca pracować na wtasnym, „Gazeta Prawna", z dnia 15.06.2010.

Dictionary.LaborLawTalk.com.

Doing Business 2010, 2011, The International Bank for Reconstruction and Development/The World Bank.

Dokument roboczy Sekcji Jednolitego Rynku, Produkcji i Konsumpcji w sprawie samozatrudnienia, Europejski Komitet Ekonomiczno-Społeczny, Bruksela 2012.

Gąsiorowska E., Witczak-Roszkowska D., Portret osób przedsiębiorczych, [w:] Piech K., Kulikowski M. (red.), Przedsiębiorczośc, szansą na sukces rządu, gospodarki, przedsiębiorstw, spoteczeństwa, Instytut Wiedzy, Warszawa 2002.

Kent C. A., Rola przedsiębiorcy w gospodarce, [w:] Kamerschen D. R., McKenzie R. B., Nardinelli C., Ekonomia, Fundacja Gospodarcza NSZZ, Gdańsk 1993.

Lemańska-Majdzik A., Czynniki sukcesu firm porwstatych w wyniku samozatrudnienia, Uniwersytet Łódzki, Łódź 2006.

Lemańska-Majdzik A., Stawasz E., Samozatrudnienie - aktywne formy przeciwdziatania bezrobociu - doświadczenia krajowe i zagraniczne, [w:] Skłodowski H., Stawasz E. (red.), Psychologiczne wyznaczniki poszukiwania pracy i samozatrudnienia w regionach zmarginalizowanych, Uniwersytet Łódzki, Łódź 2007.

Piasecki B., Przedsiębiorczośc $i$ mata firma. Teoria i praktyka, Wydawnictwo Uniwersytetu Łódzkiego, Łódź 1998. 
Pisarczyk Ł., Różne formy zatrudnienia, Dom Wydawniczy ABC, Warszawa 2003. Raport o stanie sektora MSP w Polsce w latach 2004-2005, PARP, Warszawa 2005. Raport o stanie matych średnich przedsiębiorstw w Polsce, PARP, Warszawa 2011.

Skowron E., Efektywnośc polityki wtadz lokalnych we wspieraniu rozwoju przedsiębiorczości na przyktadzie regionu częstochowskiego i tódzkiego, [w:] N. Daszkiewicz (red.), Mate i średnie przedsiębiorstwa. Szanse i zagrożenia rozwoju, CeDeWu.pl, Warszawa 2007.

Warzecha A., Przedsiębiorczość a rozwój regionalny w warunkach kryzysu gospodarczego, referat na konferencję naukową „Uwarunkowania polityki rozwoju regionu - wymiar społeczny, gospodarczy i środowiskowy", Politechnika Opolska, Wydział Zarządzania i Inżynierii Produkcji, Opole 21-23 czerwca 2010.

Woźniakowski Z., Samozatrudnienie - sposób na bezrobocie, „Gazeta Prawna”, 2002, nr 39.

http://alinawarzecha.blogspot.com/2011/09/przedsiebiorczosc-polakow.html. www.samozatrudnieniu.pit.pl. 
